\title{
HOW AN AMERICAN PLAINTIFF'S LAWYER PRESENTS THE SPINAL CORD INJURY RESULTING FROM TRAUMA
}

\author{
By Richard D. Grand, J.D. \\ I77 N. Church, Suite 800, Tucson, Arizona, U.S.A.
}

Abstract. The author, a lawyer, describes how he learns the full implications of how spinal cord injury has affected his client. He teaches this to the jury and by describing the economic effects of the injury and its effect of the patient and his family, he obtains the maximum financial compensation.

Key words: Spinal cord injury; compensation; disability assessment; legal practice.

A DECLARED principle of American jurisprudence commands that where one is innocently injured due to the careless act of another, the injured shall be compensated for his injuries so as to once again make him 'whole'. Representing a spinal cord injury presents an attorney with the most severe test of his ability to educate the lay jury in order that they may understand the true realities of such a devastating injury and award that amount of money damages required to make the cord-injured person 'whole'.

In theory, the application of American law to the injury is not complex: the patient is entitled to that amount which will compensate him for the difference between his condition before and after the injury. The greatest problem for the attorney is not the application of law to fact, but rather the ability to skilfully, and to a level of lay understanding, present to the jury the physiological, psychological and financial devastation which follows a spinal cord injury.

\section{Understanding the Injury}

Before planning the process by which he will convey to the jury the consequences of a spinal cord injury, the trial lawyer must first possess a complete understanding of the injury itself. A trial of this nature is a learning process for the jury. Accordingly, it is essential in the early stages that there be a close working relationship with the attending physician who must educate the attorney in order that he may in turn educate the jury. The attorney must be aware that a spinal cord injury involves far-reaching complications which accompany the paralysis of the extremities.

Working with the attending physician, the patient's attorney learns the causes and consequences of pressure sores, autonomic dysreflexia and other attendant problematical conditions. He must appreciate that the patient may require an air-conditioned living environment and advise the jury to take this cost into consideration when deliberating upon the verdict. The attorney must also realise that if a quadriplegic is not able to sleep in a prone position he will require attendants to reposition his body during the night in order to avoid pressures sores.

Only after the attorney completely understands the nature of the injury is he able to prepare the manner by which he will present the evidence to the jury. 


\section{Educating the Jury}

Not only is the jury comprised of individuals who have never sustained a spinal cord injury, in all probability they have never known a paraplegic or quadriplegic. If they have had occasion to become acquainted with a person who has sustained such an injury, they have probably seen only that portion of the patient's life which reflects an individual who, but for the fact he may have an inability to use his hands and is confined to a wheelchair, otherwise appears normal.

Through the use of a film, usually entitled 'A Day in the Life of (the Patient)', the jury is brought face to face with the stark reality of a spinal cord captivity. Usually running for a length of 30 to 45 minutes, the film depicts the life of a paraplegic or quadriplegic from the moment he awakens until he goes to sleep. The difficulties of moving from one place to another, digital bowel cleaning, changing of the catheter, washing, dressing, eating and other daily matters which those possessed with an able body take for granted, are graphically demonstrated to aid the jury in appreciating the magnitude of the loss which the individual has sustained. In this manner the jury gains a clear understanding of the enormity of the injury and arrives at an informed appraisal of the amount of damages which will once again make the patient 'whole'.

\section{Economic Considerations}

Not only is the spinal cord patient subjected to the most crippling of injuries, but he is also thrown into the dismal abyss of economic devastation. One of the greatest burdens placed upon the plaintiff's attorney is presenting the past and future medical expenses of the patient in order that his client is fairly and adequately compensated for these out-of-pocket expenditures.

When one considers the expense required to maintain a quadriplegic (e.g. routine medical follow-up, medications, consumable medical supplies, hospital re-admissions for major complications, attendant care, equipment replacement and repair, expenses for home modification, etc.), it is quickly demonstrated why these expenses may approach large sums of money.

The American judicial system allows the patient but one day in court; consequently, he must be paid at one time for lifetime expenses. To pinpoint these future costs, the patient's trial attorney generally utilises the expertise of an economist to explain to the jury that the expenses today will be increased tomorrow due to the effects of inflation. The economist then presents his opinion concerning the impact future inflation will have upon the expenses.

Accompanying the past and future expenses required for maintaining the patient are those damages which have been incurred in lost income should the patient be unemployable. In order to place the injured patient in the position he would have been but for the injury, the jury must award an additional amount equal to the lost income incurred for the patient's work-life expectancy. As in all items of future out-of-pocket economic loss, a qualified economist may testify to accurately project the lost earnings resulting from the injury.

\section{The Injury as it Affects the Patient and his Family}

The most important aspect of a case involving a spinal cord injury involves presenting the effects of the injury on the patient and his family. Following the guideline that the jury is instructed by the judge to return an award which will 
compensate the patient for his pain, suffering, discomfort, embarrassment, humiliation and, most importantly, the loss of enjoyment of living as a normal individual, the trial attorney endeavours to present a portrait of the patient as he was before the injury and as he is presently.

The effects of the injury are mind-shattering. Along with the attending physician, such as a neurologist or physiatrist, who explains the nature and extent of the injury, a psychiatrist is generally called to accurately relate the total psychological disruption to the patient and his family.

In order for the jury to become acquainted with the patient's pre-injury life style, fellow workers and friends may be called to testify. These lay witnesses provide a valuable and candid insight to both demonstrable and subtle changes they have come to recognise as the result of a devastating injury. This presentation of the patient 'before and after' comprises a key element in the educational process of the jury.

The impact of the injury on the patient's spouse may indeed be as overwhelming as to the patient himself. Recognising this concomitant injury, the law provides for and protects the marital partner's right to an undisturbed conjugal relationship-physically, sexually and psychologically. Accordingly, where another's careless or wrongful act interferes with this right, the spouse is entitled to compensation for this loss of society and consortium.

\section{Conclusion}

With the aid of the attending physicians, motion pictures, economic experts and friends of the patient, the trial attorney presents the sobering life-style of a cord-injured patient to the jury. Although the jury views the trial in coherent sequences of testimony and exhibits, the attorney has spent literally hundreds of days preparing for the trial. The end result is, hopefully, a verdict in an amount which will fairly and adequately compensate the cord-injured person for the monumental injuries he has sustained as well as the future expenses that he will necessarily incur.

\section{SUMMARY}

This short paper is confined to describing the process by which the lawyer obtains the maximum financial compensation for his client. Wider considerations of the involvement of the lawyer in the patient's treatment and rehabilitation have been previously described by Golman (1975). The effects of inadequate and of excessively large financial settlements on the patient and his family as well as on the lawyer, doctor and society at large, require further study.

\section{RÉSUMÉ}

L'auteur, un avocat, décrit comme il a appris a voir les problèmes de ses clients qui ont subit une paraplégie. Il fait comprendre ces faits aux juges et en expliquant les suites économiques pour ses clients et leurs familles il réussit a obtenir pour eux la compensation financière maximale.

\section{ZUSAMMENFASSUNG}

Der Autor, ein Rechtsanwalt, beschreibt, wie er gelernt hat, die volle Tragweite der Querschnittslaehmung seiner Klienten zu begreifen. Er macht dies dem Gericht klar, und indem er die oekonomischen Folgen der Querschnittslaehmung fuer den Patienten und dessen Familie schildert, erwirkt er fuer ihn die hoechstmoegliche finanzielle Entschaedigung.

\section{REFERENCE}

Golman, S. L. (1975). Medicine and the law. Paraplegia, I2, 237. 